\title{
Temperature dependent characteristics of a recombinant infectious hematopoietic necrosis virus glycoprotein produced in insect cells
}

\author{
Kenneth D. Cain ${ }^{1, *}$, Katherine M. Byrne ${ }^{1}$, Alberta L. Brassfield ${ }^{1}$, Scott E. LaPatra ${ }^{2}$, \\ Sandra S. Ristow ${ }^{1, * *}$
}

${ }^{1}$ Department of Animal Sciences, Washington State University, Pullman, Washington 99164, USA

${ }^{2}$ Research Division, Clear Springs Foods, Inc., PO Box 712, Buhl, Idaho 83316, USA

\begin{abstract}
A recombinant infectious hematopoietic necrosis virus (IHNV) glycoprotein (G protein) was produced in insect cells using a baculovirus vector (Autographa californica nuclear polyhedrosis virus). Characteristics of this protein were evaluated in relation to native viral $G$ protein. A full-length $(1.6 \mathrm{~kb}) \mathrm{cDNA}$ copy of the glycoprotein gene of IHNV was inserted into the baculovirus vector under control of the polyhedrin promoter. High levels of $\mathrm{G}$ protein (approximately $0.5 \mu \mathrm{g} / 1 \times 10^{5}$ cells) were produced in Spodoptera frugiperda (Sf9) cells following recombinant baculovirus infection. Analysis of cell lysates by sodium dodecyl sulfate polyacrylamide gel electrophoresis (SDS-PAGE) and Western blot revealed a recombinant IHNV G of slightly higher mobility on the gel than the viral G protein. Differences in mobility were abrogated by endoglycosidase treatment. When the recombinant $G$ protein was produced in insect cells at $20^{\circ} \mathrm{C}\left(\mathrm{RecG}_{\mathrm{low}}\right)$, immunostaining and cell fusion activity demonstrated surface localization of the protein. In contrast, when recombinant protein was produced at $27^{\circ} \mathrm{C}$ $\left(\operatorname{Rec} G_{\text {high }}\right), G$ protein was sequestered within the cell, suggesting that at the 2 different temperatures processing differences may exist. Eleven monoclonal antibodies (MAbs) were tested by immunoblotting for reactivity to the recombinant $G$ protein. All 11 MAbs reacted to the reduced proteins. Four MAbs recognized both $R e c G_{h i g h}$ and $R_{e c} G_{\text {low }}$ under non-reducing conditions; however, 1 neutralizing MAb (92A) recognized $R e c G_{10 w}$ but failed to react to $R C_{G_{h i g h}}$ under non-reducing conditions. This suggests that differences exist between $R_{e c} G_{l o w}$ and $R e c G_{h i g h}$ which may have implications in the development of a properly folded recombinant $G$ protein with the ability to elicit protective immunity in fish.
\end{abstract}

KEY WORDS: IHNV · G protein - Baculovirus - Recombinant · Conformational alterations · Monoclonal antibodies

\section{INTRODUCTION}

Infectious hematopoietic necrosis virus (IHNV), a fish rhabdovirus causing severe disease in trout and salmon populations, results in large economic impacts to public and private aquaculture. Epizootics occur primarily in juvenile sockeye salmon (kokanee) Oncorhynchus nerka, chinook salmon $O$. tshawytscha and rainbow trout (steelhead) O. mykiss (Wolf 1988). Once considered enzootic to countries bordering the North

\footnotetext{
- Present address: University of Technology, Sydney, Immunobiology Unit, St. Leonards Campus, Gore Hill, New South Wales 2065, Australia

•.Addressee for correspondence. E-mail: ristow@wsu.edu
}

Pacific Rim, the virus has spread and is now found in continental Europe (Hattenberger-Baudouy et al. 1989). No chemotherapeutic treatments exist, and commercially licensed vaccines aimed at mass immunization of juvenile fish are not available. Only through avoidance is the disease controlled (Winton 1991).

Vaccine development against IHNV has included formalin-killed whole virus preparations (Nishimura et al. 1985), attenuated virus (Leong et al. 1988), recombinant subunit vaccines (Gilmore et al. 1988), and more recently, DNA vaccines (Anderson et al. 1996). Killed and live virus vaccines provide protection, but regulatory concerns, cost of production, and storage problems have inhibited commercial licensing. This situation has prompted development of recombinant 
subunit vaccines expressing epitopes of the glycoprotein of IHNV in Escherichia coli. These have been reported to provide protection against viral challenge in the laboratory (Gilmore et al. 1988, Xu et al. 1991). The glycoprotein (G) of IHNV is the only viral protein required to elicit neutralizing antibodies in salmonids (Engelking \& Leong 1989). Likewise, the surface glycoproteins of rabies and vesicular stomatitis virus (VSV) are responsible for eliciting neutralizing antibodies and protective immunity in mammals (Kelley et al. 1972, Cox et al. 1977, Wiktor et al. 1984). The glycoprotein of viral hemorrhagic septicemia virus (VHSV), another fish rhabdovirus that is prevalent in European trout farms and has an economic impact similar to that of IHNV, is also responsible for inducing protective immunity (de Kinkelin et al. 1984).

Unlike bacterial expression, insect cells provide posttranslational modifications such as glycosylation. Recombinant proteins produced in cultured insect cells often retain biological activity and are often functionally similar to their authentic counterparts (Luckow \& Summers 1988, Maeda 1989, Luckow 1991, King \& Possee 1992). For these reasons, it was thought that a full-length glycosylated G protein produced in insect cells may provide a more complete IHNV vaccine. Koener \& Leong (1990) successfully expressed the glycoprotein gene of IHNV in insect cells using a baculovirus vector. The resulting protein migrated similarly to the viral $G$ protein and reacted with anti-IHNV glycoprotein antiserum in a Western blot; however, no further characterization or testing of this recombinant protein has been reported. Research on other rhabdovirus G proteins suggests that glycosylation may be critical for neutralizing antibody formation (Machamer \& Rose 1988, Prehaud et al. 1989) Development of a baculovirus vector for expression of a full-length IHNV G gene may provide a glycosylated protein structurally similar to the viral $G$ protein. The objectives of this study were to express the IHNV G gene as a full-length recombinant protein in insect cells using a baculovirus vector and to characterize the product in relation to the wild-type viral glycoprotein.

\section{MATERIALS AND METHODS}

Virus and cells. Recombinant baculoviruses were propagated and assayed in confluent monolayers or suspensions of Spodoptera frugiperda (Sf9) cells grown in serum-free media Sf-900 II (Gibco, BRL). Sf9 cells, originally obtained from the American Type Culture Collection (ATCC \#CRL-1711), were supplied by Gibco $\mathrm{BRL}$ and maintained at 20 or $27^{\circ} \mathrm{C}$. Culture and infection of cells with recombinant baculovirus stocks followed recommendations by Gibco BRL. Recombinant baculovirus stocks were obtained by centrifugation of infected Sf9 suspension cultures $(100 \times g)$ for $5 \mathrm{~min}$, harvesting supernatant and storing at $4^{\circ} \mathrm{C}$ in the dark for later use. Purified IHNV (Round Butte I isolate; previously described in Hsu et al. 1986, Ristow \& Arnzen de Avila 1991) was used for electrophoretic analysis.

Baculovirus vector construction. Recombinant baculoviruses were constructed using the Bac-to-Bac ${ }^{\text {TM }}$ Expression System (Gibco BRL). Briefly, a cDNA copy of the full-length glycoprotein gene of IHNV was excised from the pCMV4-G plasmid (kindly provided by Dr Jo-Ann Leong, Oregon State University) by digestion with the restriction endonuclease $P_{S t I}$. The digested products were separated in low melting agarose and the $1.6 \mathrm{~kb}$ glycoprotein gene was excised. The gene was cloned into the multiple cloning site of the pFastbac-HT donor plasmid (Gibco BRL) just downstream of the polyhedrin promoter. A control gene (Gus) encoding $\beta$-glucuronidase (provided by Gibco BRL), was cloned and expressed in parallel with the $G$ gene. Donor plasmids containing each of the target cDNA inserts (Gus and IHNV G) were transformed into competent Escherichia coli DH10Bac cells (Gibco BRL) harboring a baculovirus shuttle vector (bacmid), a recombinant virus that replicates as a large plasmid and is infective to lepidopteran insect cells. Transformation occurred by site-specific transposon-mediated insertion of the target gene from the donor plasmid into a miniatt $\operatorname{Tn} 7$ site on the bacmid (Luckow et al. 1993). Four bacterial colonies containing the recombinant bacmid were chosen for transfection into Sf9 cells. Bacmid DNA from colonies $4,6,7$, and 8 was isolated and transfected into $\mathrm{Sf} 9$ cells using Cellfectin (Gibco BRL) reagent following the manufacturer's instructions. Transfection media was removed after incubation for $5 \mathrm{~h}$ at $27^{\circ} \mathrm{C}$ and replaced with fresh media. Supernatants were harvested $72 \mathrm{~h}$ post-transfection. Virus titers were determined by plaque assay (Gibco BRL), and suspension cultures of Sf 9 cells were infected at a multiplicity of infection (MOI) of 0.01 to 0.1 for amplification of virus stock. The resulting recombinant Autographa californica nuclear polyhedrosis viruses (AcNPV) containing the gene encoding the $G$ protein or the Gus ( $\beta$-glucuronidase) control were designated rAcG497, rAcG697, rAcG797, rAcG897, and rAcGus. Production of target proteins was evaluated following infection of suspension cultures of Sf9 cells at an MOI of 5 to 10.

Recombinant glycoprotein production. Separate cultures of $\mathrm{Sf} 9$ cells, grown in suspension at $27^{\circ} \mathrm{C}$, were initially mock infected or infected with 1 of the 4 recombinant baculoviruses. Cells were harvested by centrifugation at $8 \mathrm{~d}$ post-infection (dpi) and analyzed for protein production by electrophoresis and immunoblotting (described in detail below). Based on initial protein production, rAcG897 was chosen and used for all subsequent expression experiments. 
Recombinant G protein produced in Sf9 cells cultured at either 20 or $27^{\circ} \mathrm{C}$ was designated $R e c G_{\text {low }}$ or Rec $G_{\text {high }}$, respectively. Infection with rAcGus and expression of the positive control gene was accomplished at $27^{\circ} \mathrm{C}$. Protein production for RecG $G_{\text {low }}$ or RecG $G_{\text {high }}$ was evaluated by removal of $5 \mathrm{ml}$ of media plus cells daily from Day 2 to Day 14 following infection of suspension cultures of Sf9 cells with rAcG897. Harvest of cells for electrophoretic analysis was accomplished by centrifugation for $5 \mathrm{~min}$ at $100 \times g$ of baculovirus infected or mock infected cell suspensions. Following centrifugation, cell pellets were resuspended in phosphate buffered saline (PBS) and stored at $-20^{\circ} \mathrm{C}$

Electrophoresis and immunoblotting. Protein production was demonstrated by sodium dodecyl sulfate polyacrylamide gel electrophoresis (SDS-PAGE) according to previously described methods (Laemmli 1970). Recombinant proteins were evaluated by staining gels for total protein with coomassie brilliant blue or by immunoblotting. Following coomassie blue staining, protein concentrations were estimated by comparison of $\mathrm{G}$ specific bands to a band produced by $1 \mu \mathrm{g}$ of a bovine serum albumin (BSA) standard. Spot densitometry analysis was accomplished with an AlphaImager-2000 image analyzer (Alpha Innotech Corporation) and computer software (Alpha Imager-2000 3.23).

Samples were prepared for electrophoresis under both reducing and non-reducing conditions. Those samples to be analyzed under reducing conditions were boiled for $5 \mathrm{~min}$ in dissociation buffer (Laemmli 1970 ) containing $2 \%$ SDS, $3 \%$ glycerol, and $2 \%$ 2-mercaptoethanol (2-ME), while samples prepared under non-reducing conditions were treated identically except 2-ME was omitted from the dissociation buffer. Samples were loaded into wells, and SDS-PAGE was performed using pre-cast polyacrylamide gels (BioRad) containing a $4 \%$ stacking gel and either 10 or $20 \%$ separating gel and subjected to electrophoresis at $150 \mathrm{~V}$ for $1 \mathrm{~h}$. Electrophoresed proteins were transferred to nitrocellulose membranes (Bio-Rad) at $100 \mathrm{~V}$ for $1 \mathrm{~h}$ along with rainbow pre-stained protein molecular weight markers (Amersham Life Science). Blots were blocked by incubation in $5 \%$ non-fat milk for $1 \mathrm{~h}$. They were then incubated for $1 \mathrm{~h}$ or overnight with polyclonal rabbit anti-IHNV glycoprotein antiserum or supernatant from mouse hybridoma cultures containing monoclonal antibodies (MAbs) specific for the $G$ protein of IHNV. Eleven different G-specific MAbs were used in this study (Ristow \& Arnzen de Avila 1991). MAbs were tested individually and as a pool. The MAb pool was prepared by combining equal volumes of hybridoma culture supernatants from MAbs 92A(IgG $2 b), 131 \mathrm{~A}(\operatorname{IgM}), 127 \mathrm{~B}(\operatorname{Ig} M), 135 \mathrm{~L}\left(\operatorname{IgG}_{2 \mathrm{~b}}\right)$, $136 \mathrm{~J}\left(\operatorname{IgG}_{2 b}\right), 111 \mathrm{~A}\left(\operatorname{IgG}_{1}\right), 15 \mathrm{~A}(\operatorname{Ig} M), 15 \mathrm{~B}(\operatorname{Ig} M), 2 \mathrm{~F}(\operatorname{Ig} M)$, $10 \mathrm{~B}(\mathrm{IgM})$, and $151 \mathrm{~K}\left(\mathrm{IgG}_{3}\right)$. Blots were incubated for $1 \mathrm{~h}$ with either affinity purified goat anti-rabbit or rabbit anti-mouse ( $\operatorname{Ig} \mathrm{G}+\operatorname{Ig} \mathrm{A}+\operatorname{Ig} M$ ) antibodies (Zymed Laboratories, Inc) conjugated to horseradish peroxidase (HRP) and diluted 1:2000. Between all incubations, blots were washed for $10 \mathrm{~min}$ in PBS containing $0.05 \%$ tween (PBST). Protein bands were visualized by exposure to chemiluminescence reagents (Dupont NEN Research Products) for $1 \mathrm{~min}$. Finally, film was exposed to the blots and developed by autoradiography.

Deglycosylation. Purified IHNV or Sf9 cells producing recombinant $\mathrm{G}$ proteins ( $\mathrm{RecG}_{\mathrm{low}}$ or $\mathrm{RecG}_{\mathrm{high}}$ ) were deglycosylated by endoglycosidase treatment. Samples were reduced by boiling for $5 \mathrm{~min}$ in $1 \%$ SDS and $0.5 \%$ 2-ME. Preparations were diluted 2-fold in $20 \mathrm{mM}$-EDTA and $0.6 \%$ Triton X-100 in PBS to yield a cell concentration of approximately $1 \times 10^{5}$ cells ml-1. Samples were incubated with or without $1 U$ of an endoglycosidase $\mathrm{F} / \mathrm{N}$-glycosidase $\mathrm{F}$ preparation (Boehringer Mannheim) overnight at $37^{\circ} \mathrm{C}$ and analyzed by immunoblotting.

Immunostaining and $\beta$-glucuronidase (Gus) staining of $\mathrm{Sf} 9$ cells. An alkaline phosphatase immunostaining procedure, slightly modified from previous methods (Cain et al. 1996), was utilized for visualization of recombinant $G$ proteins using light and fluorescence microscopy. Monolayers of Sf9 cells were grown to confluency in 96-well flat bottom tissue culture plates (Falcon), and infected with rAcG897, rAcGus, or mock infected with serum free media. Cells were maintained at either 20 or $27^{\circ} \mathrm{C}$ and fixed at $10 \mathrm{dpi}$. Sf 9 cells were rinsed briefly with PBS and fixed in either $10 \%$ neutral buffered formalin or methanol for $15 \mathrm{~min}$. Fixation with a formalin based fixative leaves the cell impermeable to antibodies and allows visualization of surface antigens (Biberfeld et al. 1974). Following fixation, cells were again rinsed in PBS and placed at $4^{\circ} \mathrm{C}$ until staining could be performed. Staining for recombinant antigen was accomplished by blocking cells for $1 \mathrm{~h}$ in $5 \%$ non-fat milk and then incubating overnight with an MAb (136J) specific to the G glycoprotein of IHNV (Ristow \& Arnzen de Avila 1991). Cells were washed with several changes of PBST, and a 1:400 dilution of biotinylated goat antimouse IgG (Dako Corporation) secondary antibody was applied for $1 \mathrm{~h}$ at room temperature (RT). After washing with PBST and a final rinse with PBS, ABC-APase (Vector Laboratories) was applied for $30 \mathrm{~min}$ at $\mathrm{RT}$; then the Vector Red substrate (Vector Laboratories) was applied, and color developed in the dark for 5 to $10 \mathrm{~min}$. The reaction was stopped by rinsing for $5 \mathrm{~min}$ in distilled water. Cells were counterstained in Mayer's hematoxylin for $2 \mathrm{~min}$ followed by a tap water rinse for $5 \mathrm{~min}$. Positive cells appeared red against a blue background and were visualized using standard light microscopy. The stain is also highly fluorescent and was distinguished with a fluorescence microscope using a rhodamine filter. 
Staining of rAcGus-infected cells was performed using a $\beta$-glucuronidase specific staining procedure following the manufacturer's instructions (Gibco BRL, Bac-to$\mathrm{Bac}^{\mathrm{TM}}$ Baculovirus Expression System). Briefly, cells were washed with PBS containing calcium and magnesium (Gibco BRL) and fixed for $5 \mathrm{~min}$ at room temperature with a solution of PBS containing $2 \%$ formaldehyde and $0.05 \%$ glutaraldehyde. Cells were washed twice and a substrate solution $\left(1 \mathrm{mg} \mathrm{ml} l^{-1}\right.$ of X-glucuronide, $5 \mathrm{mM}$ potassium ferricyanide, $5 \mathrm{mM}$ potassium ferrocyanide, and $2 \mathrm{mM} \mathrm{MgCl}_{2}$ in PBS) was added and incubated for 2 to $18 \mathrm{~h}$ at $37^{\circ} \mathrm{C}$ depending on color development. Cells were rinsed in PBS, and $\beta$-glucuronidase positive cells (stained blue) were identified and counted. Plates were fixed in 10\% neutral buffered formalin for 10 min, rinsed with PBS and stored in PBS at $4^{\circ} \mathrm{C}$.

Cell-associated fusion activity. The ability of recombinant $G$ proteins to induce fusion of Sf 9 cells was evaluated. Monolayers of Sf9 cells grown in 24-well tissue culture plates (Corning) were mock infected, infected with rAcG897 at an approximate MOI of 10, or infected with rAcGus at an approximate MOI of 1 . Virus inocula were allowed to adsorb to cells for $1 \mathrm{~h}$, at which time media was aspirated from wells. Fresh media at $\mathrm{pH} 6.4$ (normal), 6.2, 6.0, 5.8 and 5.6, was added to designated wells, and cultures were maintained at 20 or $27^{\circ} \mathrm{C}$ for $10 \mathrm{~d}$. Syncytia formation (measured as the percentage of cells fusing/well) was monitored daily with phasecontrast microscopy.

\section{RESULTS}

\section{Glycoprotein production}

Production of the recombinant form of the IHNV G protein was demonstrated in Sf9 cells infected with

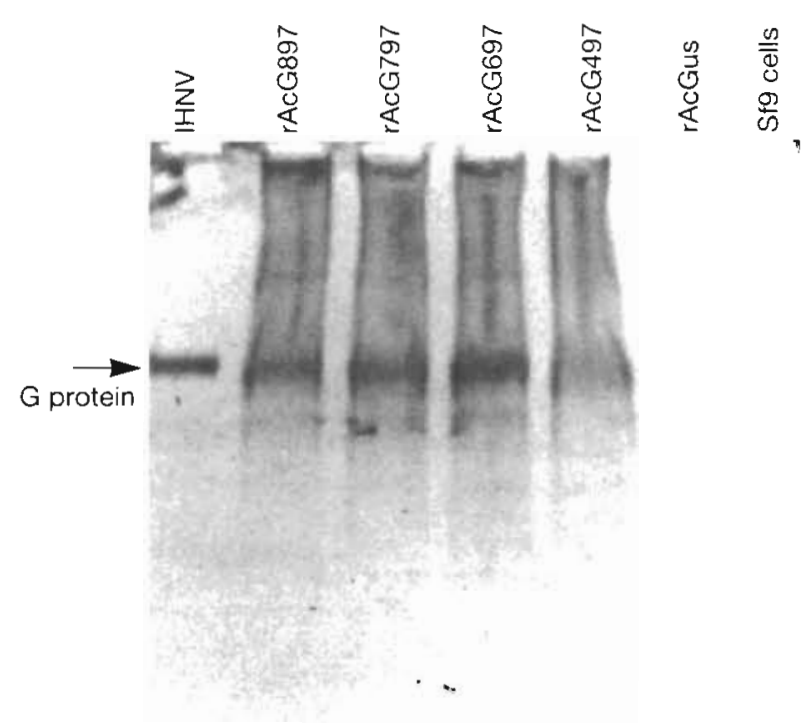

Fig. 1. Demonstration of recombinant IHNV G protein production in Sf9 cells infected with baculoviruses rAcG897, rAcG797, rAcG697, rAcG497. Proteins were transferred to a nitrocellulose membrane and detected with polyclonal rabbit anti-lHNV glycoprotein $\mathrm{Ab}$

each of the 4 initial recombinant baculoviruses containing a $1.6 \mathrm{~kb}$ cDNA insert. Immunoblotting with polyclonal rabbit anti-IHNV glycoprotein antiserum showed that the recombinant $G$ protein subjected to SDS-PAGE migrated slightly lower in molecular weight (MW) than the viral G protein of IHNV (Fig. 1). No reaction was observed with Sf9 cells or cells infected with a baculovirus containing the $\beta$-glucuronidase gene (rAcGus). Coomassie blue staining of proteins from Sf9 cells infected with $\mathrm{IACG} 897$ and harvested at $4,6,8$, and $10 \mathrm{dpi}$ following SDS-PAGE revealed bands of overproduced protein slightly lower
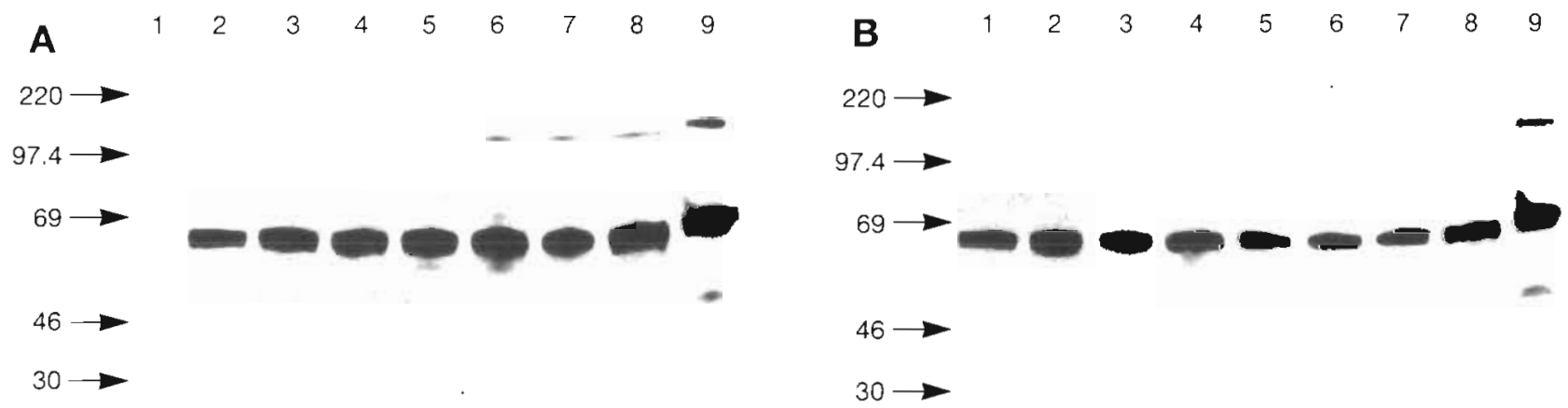

Fig. 2. Time of expression of $R_{e c G}$ iow and RecG high analysed by immunoblotting with a pool of 11 IHNV G-specific MAbs. (A) Lanes 1 to 8 , approximately $1 \times 10^{4} \mathrm{Sf} 9$ cells producing RecG $\mathrm{l}_{10 \mathrm{w}}$ at 2 to $9 \mathrm{dpi}$, respectively; lane $9,2 \mu \mathrm{g}$ purified IHNV. (B) Lanes 1 to 8 , approximately $1 \times 10^{4} \mathrm{Sf} 9$ cells producing RecG $_{\text {high }}$ at 2 to $9 \mathrm{dpi}$, respectively; lane 9, $2 \mu \mathrm{g}$ purified IHNV 
in MW than the IHNV glycoprotein (data not shown). Average density of bands corresponding to the $G$ protein in the $4,6,8$, and $10 \mathrm{dpi}$ samples was estimated by spot densitometry analysis and compared to $1 \mu \mathrm{g}$ of a BSA standard. Approximately $0.5 \mu \mathrm{gg}$ of recombinant $\mathrm{G}$ protein $/ 1 \times 10^{5}$ infected Sf9 cells was produced.

Immunoblotting with a pool of 11 different G specific MAbs (Ristow \& Arnzen de Avila 1991) showed delayed production of $\operatorname{RecG}_{\text {low }}$ when compared to $\mathrm{RecG}_{\text {high. }}$. Production of $\mathrm{RecG}_{\text {low }}$ was minimal prior to $72 \mathrm{~h}$ post-infection, while $R_{e c} G_{\text {high }}$ was detected at $48 \mathrm{~h}$ post-infection (Fig. 2). All 11 MAbs reacted in a Western blot to IHNV G, $\mathrm{RecG}_{\text {high }}$, and $\mathrm{RecG}_{\text {low }}$ following disulfide bond reduction in the presence of 2-ME. Only 111A, 2F, 151K, and 136 J reacted in the Western blot with the non-reduced form of both $\mathrm{RecG}_{\text {high }}$ and $\mathrm{RecG}_{\text {low, while }}$ all MAbs recognized the non-reduced IHNV G protein (Table 1). Of the $4 \mathrm{MAbs}$ recognizing both $\mathrm{Rec}_{\mathrm{high}}$ and RecG $G_{\text {low }}$ under non-reducing conditions, reactions were primarily to glycoprotein aggregations at the top of the gel (not shown). An additional MAb (92A) showed little reaction to protein aggregations but recognized distinct bands corresponding to reduced and non-reduced wild-type IHNV G protein and $\operatorname{RecG}_{\text {low }}$ (Fig. 3). In all cases, samples were loaded in an identical manner. In lane 2 of the figure, 3 bands are recognized and most likely represent small amounts of pro-

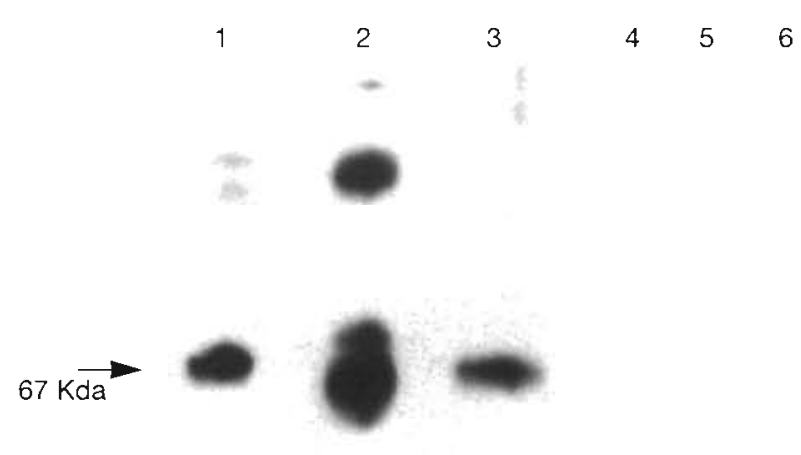

Fig. 3. Recognition of non-reduced RecG $G_{10 w}$ by $M A b 92 \mathrm{~A}$ Lane 1, reduced IHNV; lane 2, non-reduced IHNV; lane 3,

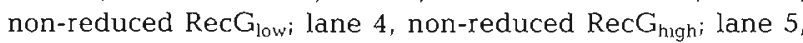
Sf9 control cells; lane 6, Gus control cells tein present as dimers and trimers in the non-reduced sample. $92 \mathrm{~A}$ was the only neutralizing MAb that reacted to the recombinant $G$ protein under nonreducing conditions, but recognition was specific to RecG $G_{\text {low }}$ and not $\operatorname{RecG}_{\text {high. }}$

Deglycosylation by overnight incubation with endoglycosidase $F$ revealed a band for each recombinant $G$ protein that reacted to MAbs in an immunoblot and corresponded to the deglycosylated IHNV G protein (Fig. 4). Whereas the glycoprotein of purified IHNV was completely deglycosylated, the G protein from recombinant $\mathrm{Sf} 9$ cells appeared only partially deglycosylated after $18 \mathrm{~h}$ of digestion. This was most likely due to the presence of high concentrations of other competing cellular glycoproteins (a possible alternate substrate for the endoglycosidase).

\section{Surface localization of the recombinant glycoprotein on $\mathrm{Si} 9$ cells}

Immunostaining of formalin-fixed Sf9 cells using MAb 136J demonstrated localization of the $G$ protein on the surface of cells grown at $20^{\circ} \mathrm{C}$ (Fig. 5B). Only rare surface staining of individual cells was observed when cells were grown at $27^{\circ} \mathrm{C}$ (Fig. $5 \mathrm{C}$ ), and no reaction to $136 \mathrm{~J}$ was detected in uninfected Sf9 controls or rAcGus-infected cells grown at either temperature. Cells fixed in methanol allowed some permeability and entry of reagents through the plasma membrane. This resulted in similar staining of surface $\mathrm{G}$ protein at $20^{\circ} \mathrm{C}$ (Fig. 5E), and cytoplasmic staining of recombinant $G$ was evident in cells grown at $27^{\circ} \mathrm{C}$ (Fig. 5F). 


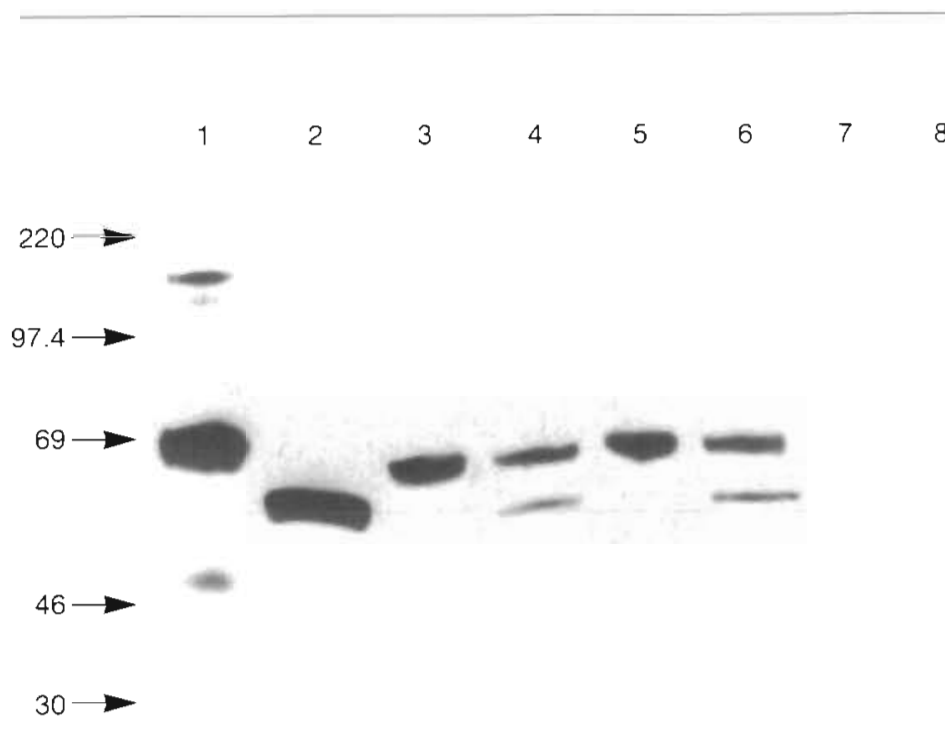

Fig. 4. Deglycosylation of $\operatorname{Rec}_{\text {high, }} \operatorname{RecG}_{\text {low' }}$ and IHNV. Lane 1, IHNV; lane 2, deglycosylated IHNV, lane 3, RecG ${ }_{\text {hugi }}$ lane 4, deglycosylated RecG ${ }_{\text {bighi }}$ lane 5, RecG $\mathrm{l}_{\mathrm{owi}}$ lane 6, deglycosylated RecGlow; lane 7, Sf9 controls; lane 8. rAcGus-infected $\mathrm{Sf} 9$ cells. All samples were incubated overnight $(18 \mathrm{~h})$ with or without endoglycosidase $\mathrm{F} / \mathrm{N}$-glycosidase $\mathrm{F}$ at $37^{\circ} \mathrm{C}$
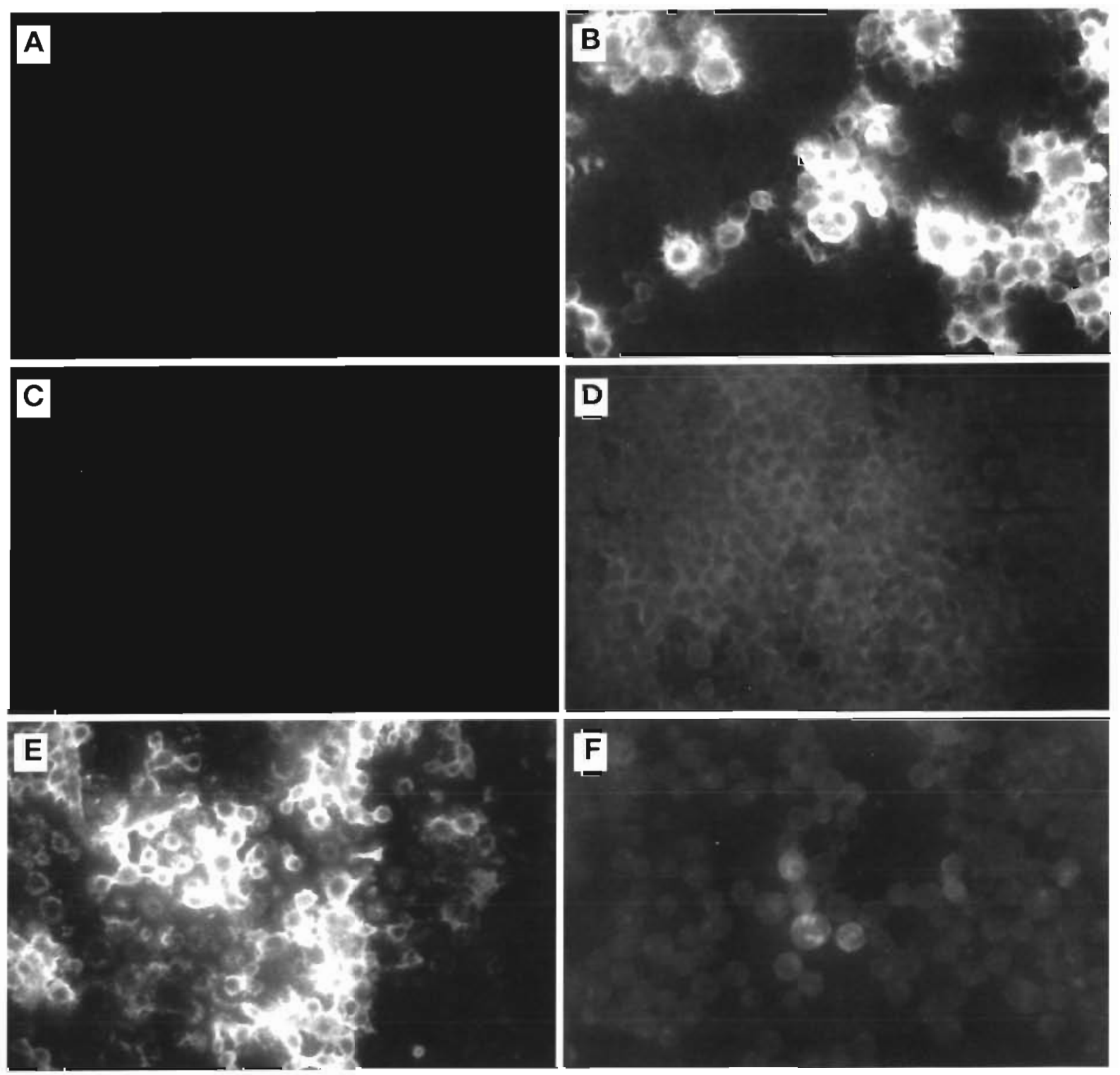


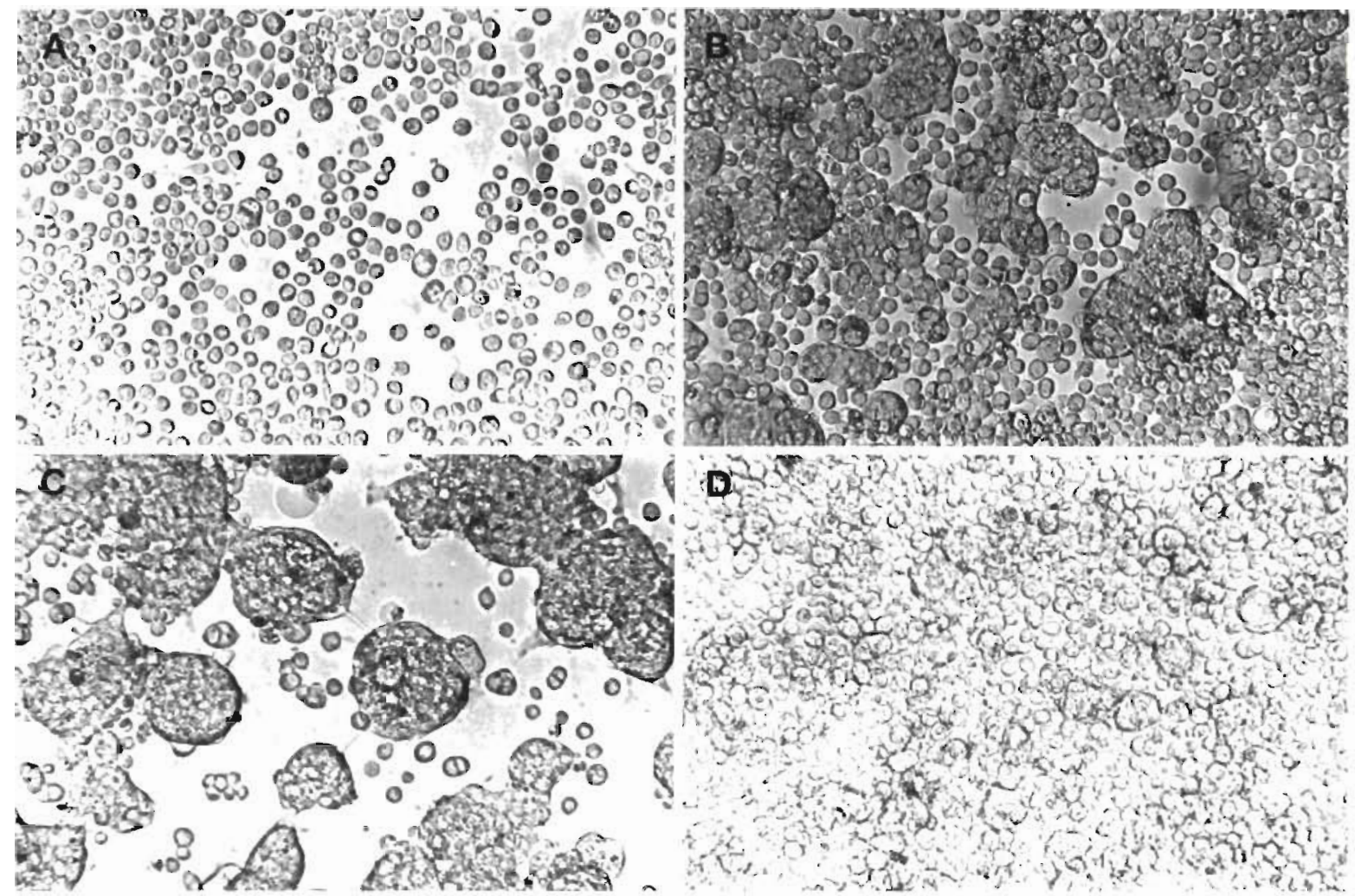

Fig. 6. Cellular fusion activity of RecG $G_{\text {low }}$ infected cells at different $\mathrm{pHs}$. (A) Sf9 cells producing RecG $\mathrm{G}_{\text {low }}(6 \mathrm{dpi})$ at $\mathrm{pH} 6.4$ (normal); (B) Sf9 cells producing RecG $G_{\text {low }}(6 \mathrm{dpi})$ at pH 5.8; (C) Sf9 cells producing RecGlow (10 dpi) at pH 5.6; and (D) Sf9 cells producing RecG $\mathrm{high}(10 \mathrm{dpi})$ at $\mathrm{pH} 5.6$

Fusion of Sf9 cells producing the recombinant IHNV glycoprotein at $20^{\circ} \mathrm{C}$ was initially observed by $5 \mathrm{dpi}$ at $\mathrm{pHs} \leq 6.2$. Cell fusion was monitored out to $10 \mathrm{dpi}$, and increased steadily in cells producing $\operatorname{RecG}_{\text {low }}$, but minimal fusion was observed in parallel cultures of $R \mathrm{G}_{\text {high }}$ cells (Fig. 6). By 9 dpi, between 25 and $100 \%$ of RecG $G_{\text {low }}$ cells exhibited fusion at all $\mathrm{pH}$ ranges (6.4 to 5.6). Fusion of cells expressing $\mathrm{Rec}_{\text {high }}$ was $<25 \%$ at all $\mathrm{pH}$ values tested in the study and was highest at $10 \mathrm{dpi}$ and pH 5.6 (Fig. 6D). No fusions were observed at either temperature with uninfected Sf9 cells, while cells infected with rAcGus and expressing the glycoprotein ( $\beta$-glucuronidase) only exhibited fusions at $27^{\circ} \mathrm{C}$.

\section{DISCUSSION}

Koener \& Leong (1990) originally expressed the IHNV G gene using baculovirus vectors and found that
MWs of the recombinant protein corresponded to the viral $G$ protein. In earlier work, the deduced $M W$ of the unglycosylated $\mathrm{G}$ protein was 56795 daltons and 5 potential glycosylation sites were identified (Koener et al. 1987). In the present study a recombinant IHNV G protein was produced in insect cells using a commercially available baculovirus expression system (Bac-to$\mathrm{Bac}^{\mathrm{TM}}$ Gibco BRL), and was found to be only partially glycosylated. The baculovirus derived $\mathrm{G}$ protein migrated faster during SDS-PAGE than the viral IHNV glycoprotein, and MW differences were due to glycosylation differences. It was therefore concluded that insect cells process the IHNV glycoprotein differently than fish cells. Similar studies of another fish rhabdovirus (VHSV) have also shown decreased levels of glycosylation when recombinant $G$ protein or wildtype virus were produced in insect cells (Lecocq-Xhonneux et al. 1994, Lorenzen \& Olesen 1995). It is known that insect cells lack certain glycosylation features

Fig. 5. Immunofluorescence microscopy using MAb 136 J and showing surface localization of recombinant G protein in Sf9 cells. (A) Formalin-fixed Sf9 cells; (B) formalin-fixed Sf9 cells producing RecG low; $_{\text {(C) formalin-fixed Sf9 cells producing RecG }}$ (Chi (D) methanol-fixed Sf9 cells; (E) methanol-fixed Sf9 cells producing RecG $\mathrm{G}_{\text {lowi }}$ and (F) methanol-fixed Sf9 cells producing RecG 
such as sialyl transferase activities (Prehaud et al. 1989), and it was found that oligosaccharide side chains of the hemagglutinin of influenza virus are smaller when produced in insect cells than when virions are produced in vertebrate hosts (Kuroda et al. 1990). Nevertheless, insect cells are generally able to produce functionally immunogenic proteins (Luckow 1991)

Effects of temperature have been reported to influence cellular processing of rhabdoviral $G$ proteins (Gibson et al. 1981, Kotwal et al. 1986). Temperature effects in relation to the recombinant IHNV G protein were investigated this study. Production of IHNV G protein in insect cells was found to be delayed slightly when Sf9 cells were grown at $20^{\circ} \mathrm{C}\left(\mathrm{RecG}_{\text {low }}\right)$ compared to $27^{\circ} \mathrm{C}\left(\operatorname{Rec}_{\text {high }}\right)$. This delayed production may be attributed to a decrease in metabolic processing at lower temperatures. Other temperature influences have been demonstrated by Lorenzen (1997) in relation to a recombinant VHSV G protein produced in insect cells. The protein appeared to fold correctly and was recognized by a conformational dependent MAb only when produced at lower temperatures. Based on Lorenzen's findings, similar temperature influences were evaluated for the glycoprotein of IHNV. Interestingly, dramatic differences were observed in the ability of insect cells to efficiently transport/localize RecG $G_{\text {high }}$ and RecG $_{\text {low }}$ to the cell surface (Fig. 5). Cell surface expression, characteristic of rhabdoviral G proteins, was demonstrated by immunostaining of formalin-fixed Sf9 cells and was only evident in cells producing $\mathrm{RecG}_{\text {low. }}$. Formalin or methanol fixation allowed the detection of either cell surface or intracellular antigen, respectively. Little or no $G$ protein was present on the surface of cells producing $\mathrm{Rec}_{\mathrm{high}}$, but intracytoplasmic staining was observed in methanol fixed cells producing $R_{e c} G_{\text {high }}$. The recombinant protein is therefore confined within cells grown at high temperatures, but expression at low temperature results in transport to the surface of cells. The temperature-associated differences observed here indicate that low temperature production of this baculovirus product may lead to a more native rhabdoviral G protein. Lecocq-Xhonneux et al. (1994) reported that only a fraction of recombinant VHSV G protein was correctly processed and exported to the surface of insect cells. They also reported that the recombinant $G$ protein was detected within cytoplasmic inclusions by immunofluorescence.

Surface localization and other rhabdoviral $G$ protein characteristics were further demonstrated by examination of cellular fusion activity in recombinant baculovirus-infected Sf9 cells (Fig. 6). Cells producing Rec$\mathrm{G}_{\text {low }}$ exhibited some level of cell fusion by 6 dpi at $\mathrm{pH}$ values between 5.6 and 6.2 with cells at the lower $\mathrm{pH}$ range showing the highest level of fusion. Fusion of cells expressing RecG $_{\text {high }}$ was minimal (<25\%) and only observed at $\mathrm{pH} 5.6$. The fusion activity observed with $\operatorname{Rec} G_{\text {low }}$ is consistent with low $\mathrm{pH}$ fusion activity of other rhabdovirus G proteins (Tuchiya et al. 1992), and the limited fusion observed with $\operatorname{RecG}_{\text {nigh }}$ supports the lack of surface expression at $27^{\circ} \mathrm{C}$. These characteristics are considered to be an important part of the natural viral infection process. It is known that $G$ proteins form trimers that are activated at low $\mathrm{pH}$ and expose hydrophobic regions at the surface which allows fusion to occur (Gaudin et al. 1993). During infection, once endocytosis occurs, fusion of the viral and host membrane occurs only after the $\mathrm{pH}$ is lowered to approximately 5 in VSV (Schlegel et al. 1982, Rigaut et al. 1991), and rabies (Superti et al. 1984). At this pH it has been shown that isolated VSV G protein undergoes conformational changes that allow the protein to simultaneously interact with the viral and host cell membranes (Brown et al. 1988). Although rhabdoviruses infecting mammals may not be directly comparable to fish rhabdoviruses, it appears that similar types of changes must occur for $\operatorname{RecG}_{\text {low }}$ to be present at the cell surface and produce similar fusion characteristics. This fusion activity has also been observed in Sf9 cells producing the recombinant $G$ protein of rabies (Tuchiya et al. 1992) and VHSV (Lecocq-Xhonneux et al. 1994). Altered post-translational processing associated with high temperature or glycosylation differences is known to result in misfolding of $\mathrm{G}$ proteins (Gallione \& Rose 1985). Since both RecG $G_{\text {high }}$ and RecG $G_{\text {low }}$ produced an underglycosylated product, it is interesting that only RecG $G_{\text {low }}$ appeared to be transported to the cell surface in a correct manner.

Further analysis of the recombinant $G$ protein by immunoblotting with 11 different $M A$ bs showed that linear epitopes were recognized for both $\operatorname{RecG}_{\text {high }}$ and Rec $G_{\text {low }}$ with no apparent differences. Interestingly, when non-reduced samples were evaluated, an epitope recognized by MAb 92A was present only for RecG $_{\text {low }}$ and not RecG $G_{\text {high }}$. 92A is an IHNV neutralizing MAb (Ristow \& Arzen de Avila 1991), and recognition of only $R_{e c} G_{\text {low }}$ under non-reduced conditions suggests this epitope may be hidden at non-permissive temperatures. Huang et al. (1994) used similar Western blot analyses to identify MAbs specific for conformation-dependent epitopes on the $G$ protein of IHNV The site identified by $92 \mathrm{~A}$ may map to an immunogenically important region that is conformationally correct only when processed at lower temperatures in insect cells. All 11 MAbs tested recognized viral IHNV $G$ protein under both reducing and non-reducing conditions at the concentrations used, which indicates that these epitopes are linear in nature and are not normally hidden due to protein folding. The fact that the recombinant $G$ proteins reacted differently to the 
MAbs is of concern and may represent unavoidable differences in protein folding associated with insect cell production in general.

The demonstration of surface localization of the recombinant IHNV G protein is considered important because this is an important factor in the infection of the cell by rhabdoviruses (Coll 1995). The data presented here provides evidence that insect cells produce a more native IHNV glycoprotein when cultured at temperatures closer to the physiological optimum of the virus. Although vaccine trials have shown that RecG $G_{\text {low }}$ lacks immunogenicity associated with attenuated strains of IHNV (Cain et al. 1998), the present results provide a further understanding of the complex nature of the IHNV glycoprotein. Increased knowledge of the structural and functional characteristics of the $\mathrm{G}$ protein may assist in the future development of an efficacious IHNV vaccine.

Acknowledgements. The authors thank Dr Neils Lorenzen for sharing ideas and observations related to work performed on VHSV. This scientific paper originates from the College of Agriculture and Home Economics Research Center of Washington State University. This work was supported in part by grants 96-38500-2674 and 97-38500-4041 from the United States Department of Agriculture to the Western Regional Aquaculture Center.

\section{LITERATURE CITED}

Anderson ED, Mourich DV, Fahrenkrug SC, LaPatra S, Shepherd J, Leong JC (1996) Genetic immunization of rainbow trout (Oncorhynchus mykiss) against infectious hematopoietic necrosis virus. Mol Mar Biol Biotechnol 5:114-122

Biberfeld P, Biberfeld G, Molnar A, Fagraeus A (1974) Fixation of cell-bound antibody in the membrane immunofluorescence test. J Immunol Methods 4:135-148

Brown JC, Newcomb WW, Lawrence-Smith S (1988) pH dependent accumulation of the vesicular stomatitis virus glycoprotein at the ends of intact virions. Virology 167 : $625-632$

Cain KD, LaPatra SE, Baldwin TJ, Shewmaker B, Jones J, Ristow SS (1996) Characterization of mucosal immunity in rainbow trout Oncorhynchus mykiss challenged with infectious hematopoietic necrosis virus: identification of antiviral activity. Dis Aquat Org 27:161-172

Cain KD, LaPatra SE, Shewmaker B, Jones J, Byrne KM, Ristow SS (1999) Immunogenicity of a recombinant infectious hematopoietic necrosis virus glycoprotein produced in insect cells. Dis Aquat Org 36:67-72

Coll JM (1995) The glycoprotein G of rhabdoviruses. Arch Virol 140:827-851

Cox JH, Dietzschold B, Schneider LG (1977) Rabies virus glycoprotein II. Biological and serological characterization. Infect Immun 15:754-759

de Kinkelin P, Bernard J, Hattenberger-Baudouy AM (1984) Immunization against viral diseases occurring in cold water. In: de Kinkelin P, Michel C (eds) Symposium on fish vaccination. Office International des Epizooties (OIE), Paris, p 167-198
Engelking HM, Leong JC (1989) The glycoprotein of infectious hematopoietic necrosis virus elicits neutralizing antibody and protective responses. Virus Res 13:213-230

Gallione CJ, Rose JK (1985) A single amino acid substitution in a hydrophobic domain causes temperature-sensitive cell-surface transport of a mutant viral glycoprotein. J Virol 54:374-382

Gaudin Y, Ruigrok RWH, Knossow M, Flamand A (1993) Low$\mathrm{pH}$ conformational changes of rabies virus glycoprotein and their role in membrane fusion. J Virol 67:1365-1372

Gibson R, Kornfeld S, Schlesinger S (1981) The effect of oligosacharide chains of different sizes on the maturation and physical properties of the G protein of VSV. J Biol Chem 256:456-462

Gilmore RD Jr, Engelking HM, Manning DS, Leong JC (1988) Expression in Escherichia coli of an epitope of the glycoprotein of infectious hematopoietic necrosis virus protects against viral challenge. Biotechnology 6:295-300

Hattenberger-Baudouy AM, Danton M, Merle G, Torchy C, de Kinkelin P (1989) Serological evidence of infectious hematopoietic necrosis in rainbow trout from a French outbreak of the disease. J Aquat Anim Health 1:126-134

Hsu Y, Engelking MH, Leong JC (1986) Occurrence of different types of infectious hematopoietic necrosis virus in fish. Appl Environ Microbiol 52:1353-1361

Huang C, Chien MS, Landolt M, Winton J (1994) Characterization of the infectious hematopoietic necrosis virus glycoprotein using neutralizing monoclonal antibodies. Dis Aquat Org 18:29-35

Kelley JM, Emerson SU, Wagner RR (1972) The glycoprotein of vesicular stomatitis virus is the antigen that gives rise to and reacts with neutralizing antibody. J Virol 10: $1231-1235$

King LA, Possee RD (1992) The baculovirus expression system: a laboratory guide. Chapman \& Hall, London

Koener JF, Leong JC (1990) Expression of the glycoprotein gene from a fish rhabdovirus by using baculovirus vectors. J Virol 64:428-430

Koener JF, Passavant CW, Kurath G, Leong JC (1987) Nucleotide sequence of a cDNA clone carrying the glycoprotein gene of infectious hematopoietic necrosis virus, a fish rhabdovirus. J Virol 61:1342-1349

Kotwal GJ, Buller RML, Wunner WH, Pringly CR, Ghosh MP (1986) Role of glycosylation in transport of vesicular stomatitis virus envelope glycoprotein. A new class of mutant defection in glycosylation and transport of $\mathrm{G}$ protein. J Biol Chem 261:8936-8943

Kuroda K, Geyer H, Geyer R, Doerfler W, Klenk HD (1990) The oligosaccharides of influenza virus hemagglutinin expressed in insect cells by a baculovirus vector. Virology $174: 418-429$

Laemmli UK (1970) Cleavage of structural proteins during the assembly of the head of bacteriophage T4. Nature (London) 277:680-685

Lecocq-Xhonneux F, Thiry M, Dheur I, Rossius M, Vanderheijden N, Martial J, de Kinkelin P (1994) A recombinant viral haemorrhagic septicaemia virus glycoprotein expressed in insect cells induces protective immunity in rainbow trout. J Gen Virol 75:1579-1587

Leong JC, Fryer JL, Winton JR (1988) Vaccination against infectious hematopoietic necrosis virus. In: Ellis $\mathrm{AE}$ (ed) Fish vaccination. Academic Press, London, p 193-203

Lorenzen $N$ (1997) The glycoprotein of VHS virus. In: New approaches to viral diseases of aquatic animals. Proceedings of the NRIA International Workshop, Kyoto, p 58-65

Lorenzen N, Olesen NJ (1995) Multiplication of VHS virus in insect cells. Vet Res 26:428-432 
Luckow VA (1991) Cloning and expression of heterologous genes in insect cells with baculovirus vectors. In: Prokip A, Bajpai RK, Ho C (eds) Recombinant DNA technology and applicatıons. McGraw-Hill, New York, p 97-152

Luckow VA, Summers MD (1988) Signals important for highlevel expression of foreign genes in Autographa californica nuclear polyhedrosis virus expression vector. Virology 170:31-39

Luckow VA, Lee SC, Barry GF, Olins PO (1993) Efficient generation of infectious recombinant baculoviruses by site-specific transposon-mediated insertion of foreign genes into a baculovirus genome propagated in Esherichia coli. J Virol 67:4566-4579

Machamer CE, Rose JK (1988) Vesicular stomatitis virus G proteins with altered glycosylation sites display temperature-sensitive intracellular transport and are subject to aberrant intermolecular disulfide bonding. J Biol Chem 263:5955-5960

Maeda S (1989) Expression of foreign genes in insects using baculovirus vectors. Annu Rev Entomol 34:351-372

Nishimura $T$, Sasaki $H$, Ushiyama $M$, Inoue $K$, Suzuki $Y$, Ikeya F, Tanaka M, Suzuki H, Kohara M, Arai M, Shima N Sano T (1985) A trial of vaccination against rainbow trout fry with formalin killed IHN virus. Fish Pathol 20 (2/3): $435-443$

Prehaud C, Takehara K, Flamand A, Bishop DHL (1989) Immunogenic and protective properties of rabies virus glycoprotein expressed by baculovirus vectors. Virology 173:390-399

Rigaut KD, Birk DE, Lenard J (1991) Intracellular distribution

Editorial responsibility: Jo-Ann Leong,

Corvallis, Oregon, USA of input vesicular stomatitis virus proteins after uncoating. J Virol 65:2622-2628

Ristow SS, Arnzen de Avila J (1991) Monoclonal antibodies to the glycoprotein and nucleoprotein of infectious hematopoietic necrosis virus (IHNV) reveal differences among isolates of the virus by fluorescence, neutralization an electrophoresis. Dis Aquat Org 11:105-115

Schlegel R, Willigan MC, Pastan IH (1982) Saturable binding sites for vesicular stomatitis virus on the surface of Vero cells. J Virol 43:871-875

Superti F, Derer M, Tsiang H (1984) Mechanism of rabies virus entry into CER cells. J Gen Virol 65:781-789

Tuchiya K, Matsuura Y, Kawai A, Ishihama A, Ueda S (1992) Characterization of rabies virus glycoprotein expressed by recombinant baculovirus. Virus Res 25:1-13

Wiktor TJ, McFarlan RI, Reagan KJ, Dietzschold B, Curtis PJ, Wunner WH, Kieny MP, Lathe R, Lecocq JP, Mackett M, Moss B, Koprowski H (1984) Protection from rabies by a vaccinia virus recombinant containing the rabies virus glycoprotien gene. Proc Natl Acad Sci USA. 81:7194-7198

Winton JR (1991) Recent advances in detection and control of infectious hematopoietic necrosis virus in aquaculture. Annu Rev Fish Dis 1:83-93

Wolf K (1988) Fish viruses and fish viral diseases. Cornell University Press, Ithaca, p 217-249

Xu L, Mourich DV, Engelking HM, Ristow S, Arnzen J, Leong JC (1991) Epitope mapping and characterization of infectious hematopoietic necrosis virus glycoprotein, using fusion proteins synthesized in Escherichia coli. J Virol 65: $1611-1615$

Accepted: October 6, 1998

Proofs received from author(s): April 9, 1999 